\title{
Corporate Social Responsibility and Stock Performance-Evidence from Taiwan
}

\author{
Yungchih George Wang \\ Department of International Business, National Kaohsiung University of Applied Sciences, Chinese Taipei \\ E-mail: gwang@cc.kuas.edu.tw \\ Received July 21, 2011; revised August 28, 2011; accepted September 15, 2011
}

\begin{abstract}
Traditionally, a firm aims to achieve the goal of maximizing firm value. The concept of business ethics arises to examine how a firm could meet the goal of maximizing firm value while in the meantime meditating the conflicts among all the stakeholders ethically. Recently, the concept of business ethics evolves into corporate social responsibility (CSR), which now has become a major issue in the business environment. The modern definition of CSR argues that a firm, as a corporate citizen, is expected not only to fulfill its economic responsibility, but also its social and environmental responsibilities. Built on this new definition, this study aims to empirically explore the impact of fulfilling CSR on stock performance. For this research purpose, we construct a local CSR index (CSRI) based on two ideas, socially responsible investment (SRI) and corporate contributions to stakeholders. Sampled the data from Taiwan Stock Exchange and Taiwan Economic Journal for the time period of 2001-2009, three CSR portfolios based on the CSRI (high, medium, and low) are constructed to examine short-run and long-run stock returns relative to those of benchmark portfolios (market index, value stocks, and growth stocks). The main finding reveals that fulfilling CSR has a significantly positive impact on stock performance. The implication suggests that a firm could serve as a good corporate citizen, while in the meantime pursuing the growth of stockholder's wealth.
\end{abstract}

Keywords: Business Ethics, Stakeholders, Corporate Social Responsibility, Firm Performance, Socially Responsible Investment

\section{Introduction}

A firm operates to make profits in order to maximize wealth for its stockholders. Since stockholder's wealth originates from the value of a firm, maximizing stockholder's wealth is equivalent to maximizing firm value. In the pursuit of increasing firm value, corporate operation, however, may result in the issues of business ethics and morality. For example, a food company may mingle artificial substance into its products for the purpose of a better taste while its production complies with government inspections and regulations but might potentially harm human health in the long run due to accumulation of the substance. These examples therefore lead to a voice in society calling for reestablishing the value of business ethics. Moreover, there are numerous accidents regarding how a firm's production process causes serious concerns in environmental pollution and public safety. With the rising consciousness of environmental protec- tion and global warming, people are no longer satisfied with the passive behavior of an ethical firm. Instead, firms are expected to more proactively fulfill their corporate social responsibility (CSR) as corporate citizens to economy, society, and country. The demand for a firm's fulfilling its corporate social responsibility has not only become an important issue but also a global common consensus. Therefore, firms are expected to be cautious about maintaining a balance between corporate growth and social progress when pursing their financial performance.

The importance of corporate social responsibility is further enhanced by the changes of social status in recent years. In the trend of globalization with numerous ongoing mergers and acquisitions, the fortune of major stockholders is accumulated due to economy of scale and expansion of business scope, while those who could not benefit from corporate mergers and acquisitions, on the other hand, are exploited. The consequence is that the 
gap between the wealthy and the poor is worsened. Ohmae [1] thus argues the emergence of an M-shaped society, which proposes that as the world economy develops more into globalization, the rich people exploit their knowledge advantages to rapidly accumulate fortune and in the meantime the middle class is forced to fall into a lower level of income due to the loss of their competitive advantages. Consequently, in the wealth re-distribution process, the numbers of the high-income households and the low-income ones are both increased. As firms are growing larger in size, firms are demanded to take more social responsibility to reduce social conflicts.

As discussed earlier, the demand for environmental protection, the emphasis of corporate governance, and the changes in social status are the major factors that force firms to take more social responsibilities. Due to the increasing importance of corporate social responsibility, international institutions thus embark on assessing market performance of socially responsible firms. For instance, Dow Jones \& Company, Inc, established Dow Jones Sustainability Indexes (DJSI) in 1999 and Financial Times of UK founded the Financial Times Stock Exchange for Good Index (FTSE4Good) in 2001. Not only the US and the UK, but also the other developed countries have endeavored to establish a market mechanism for evaluating a firm's efforts in fulfilling their social responsibility. These mechanisms considerably encourage firms to increase their socially responsible investment (SRI) to meet expectations from the society.

Literature indicates that the incentives of a firm's fulfilling its corporate social responsibility are not only due to social pressure or benevolence, but also based on more practical reasons associated with firm performance. As argued by Porter and Kramer [2], corporate social responsibility should be seen as one of core business strategies in a firm, implying that the firm could benefit from its social investment. Some studies suggest that when a firm implements its corporate social responsibilities, these benevolent actions could bring about employee's ethical behavior, thus contributing to a better organizational efficiency [3-5]. Other studies see corporate social responsibility as the means of conducting marketing strategies [6,7]. Maignan, Ferrell, and Ferrell [6] suggest that most firms fulfill their corporate social responsibilities because management believes that these corporate actions could improve corporate image and strengthen the effects of marketing tactics, thus having a positive relationship with firm performance.

Continued from earlier research, this study aims to investigate how the fulfillment of corporate social responsibility would impact on corporate stock performance. For this research purpose, a corporate social responsibility index (CSRI), including three dimensions, i.e., eco- nomic, social, and environmental dimensions, is constructed on the ground of the idea originated from Dow Jones Sustainability Index. We then construct three CSR portfolios, i.e., high CSR, medium CSR, and low CSR, to compare their portfolio returns to those of benchmark portfolios (market index, value stocks, and growth stocks) in the short-run and the long-run. The data are sampled from publicly-listed companies in Taiwan Stock Exchange (TWSE) and provided from Taiwan Economic Journal (TEJ) for the period of 2001-2009.

In addition to this section of introduction, the rest of the paper is given as follows: Section 2 provides literature review related to corporate social responsibility. Section 3 states research methodology. Section 4 provides research result. Finally, the concluding remark is given in Section 5.

\section{Literature Review}

\subsection{Business Ethics and Corporate Social Responsibility}

The concept of corporate social responsibility is originnated from the idea of business ethics and the expectation toward an ethical firm. Business ethics is also named corporate ethics, which is first developed upon personal ethics and morality and then extended to the application in business situations. In other words, business ethics concentrates on analyzing the problems in business activities from the perspective of morality and ethics. Vyakarnam, Baily, Myers, and Burnett [8] classified ethical issues encountered by small and medium firms into four categories: corporate activities, conflict between individual value and corporate demand, social responsibility, and conflict between owner's personality and ethical issues. As suggested in [9], the issues of business ethics could be fallen into one of the following five categories: products, human resource, environment, society and others. Rosenthal and Buchholz [10] proposed that business ethics and environmental ethics should be related to corporate social and environmental responsibilities.

Although the concept of business ethics was similar to that of corporate social responsibility, their differences rested on the definition and scope. According to [11], corporate social responsibility was defined as corporate behavior associated with the fulfillment of business ethics. In fact, there was a causal relationship between business ethics and corporate social responsibility. However, Ferrell and Geoffrey [12] argued that although both ideas were similar, yet their implications were different in that the conceptual scope of corporate social responsibility was more comprehensively defined than business ethics. 
Business ethics determined the acceptable standards of business behaviors, while corporate social responsibility was more broadly extended to corporate obligations and commitments toward the benefits of society.

Regarding the definition of corporate social responsebility, Davis and Blomstrom [13] suggested that corporate social responsibility reflects social expectation toward firms. According to [14], corporate social responsebility was also defined as social expectation to a firm regarding how the firm would repay to the society. Wood [15] further defined corporate social responsibility as the allocation of corporate resources, which reflected how a firm's social behavior could satisfy social expectation toward the firm. Recent studies (such as $[16,17]$ ) suggested that corporate social responsibility was an extension of business ethics and management morality, which should not only meet legal regulations, but also respond to public pressure and social expectation. Summarized from the literature, corporate social responsibility could be defined as the principles of business ethics to maintain the benefits of all company stakeholders. In this definition, corporate growth and social growth should be two equivalently important goals pursued by a firm in order to obtain sustainable development in economy.

Regarding the scope of corporate social responsibility, Carroll [18] contended that corporate social responsibility should be built upon a four-level pyramid, as shown in Figure 1. The bottom level of the pyramid was economic responsibility, meaning that the fundamental social responsibility of a firm was to satisfy economic needs in economy. Economic responsibility was the important base of implementation of other corporate social responsibilities. Above economic responsibility, a firm should fulfill its legal responsibility, which meant that the firms should abide by the laws and follow the rules of the game to uphold social justice. The third level of cor-

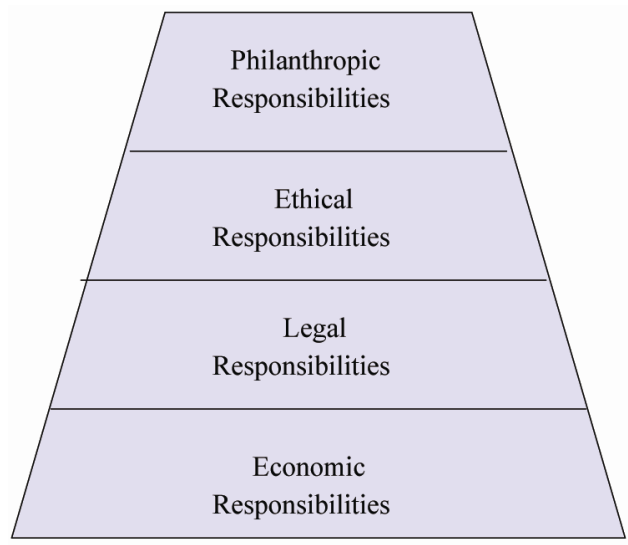

Figure 1. The pyramid of corporate social responsibility (Carroll, 1991). porate social responsibility was ethical responsibility, meaning that a firm should comply with the principles of business ethics in order to maintain peace in society. On the top level of the pyramid was human responsibility, which suggested that a firm should serve as a good corporate citizen to improve overall living quality in human society.

\subsection{International Trends of Corporate Social Responsibility}

In the trend of globalization, the idea of corporate social responsibility has drawn attentions in international capital markets. Many international organizations thought highly of corporate social responsibility as a new corporate value by evaluating a firm's socially responsible investment (SRI) in society. For instance, Down Jones, Stoxx and Sustainability Asset Management Co., in 1999, constructed the first indexes in the world, Dow Jones Sustainability World Indexes (DJSI World), attempting to evaluate stock performance of socially responsible firms. The screening standards of DJSI World were built on corporate contributions to economy, society, and environment, as exhibited in Figure 2. Each dimension was constructed by various variables to measure corporate contributions to serve the particular purpose in the dimension.

Following the U.S., London Stock Exchange in the U.K. also constructed Financial Times Stock Exchange for Good Index Series (FTSE4GOOD) in 2001. FTSE4Good Index Series consisted of most global firms with prominent implementation of social responsibility around the world. The firms included in the index must be the ones devoted to sustainable development of environment, corporate governance of economy, and human rights of international society. Since FTSE4Good Index Series aimed to evaluate corporate performance of SRI, non-

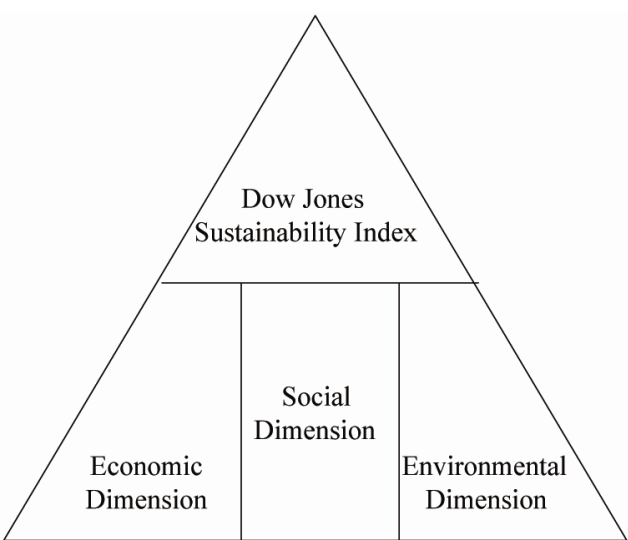

Figure 2. The design concept of dow jones sustainability index (DJSI). 
financial firm performance associated with social responsibility was appraised. In addition to the U.S. and the U.K., many other countries such as Australia, Malaysia, and Taiwan have attempted to construct their own socially responsible index.

\subsection{Corporate Social Responsibility and Firm Performance}

Since fulfilling corporate social responsibility was regarded as a socially responsible investment of a firm, how the implementation of corporate social responsibility would impact on firm performance was of special interest to academia. For example, Laczniak and Murphy [3] argued that a firm, devoted to developing the culture of business ethics, would avoid incurring individual, organizational, and social costs, thus leading to a better firm performance. Sims and Kroeck [4] suggested that a firm following the principles of business ethics could enhance employees' satisfaction and corporate identity, both of which were beneficial to organizational performance. Preston and O'Bannon [5] demonstrated that a socially responsible firm would build a more complete managerial system and firm performance thus could be improved. In addition, since the benefits of stakeholders would be considered in the decision-making process, the firm would receive a higher satisfaction from stakeholders. Furthermore, Verschoor [19] examined the financial data of the S\&P 500 firms and concluded that corporate social responsibility has a causal relationship with firm performance. It is found that corporate social responsibility could possibly reduce corporate operation costs or increase their competitive advantages.

Recent studies on CSR were directed to the linkage with business marketing, suggesting that when a firm fulfilled its corporate social responsibility, it would greatly strengthen corporate image on the customer side, thus improving firm performance. (See $[6,7,20]$ ) Both Maignan and Ferrell [20] and Maignan et al. [6] argued that the fulfillment of corporate social responsibility would enhance marketing advantages and reinforce corporate identity of stakeholders. This argument was too conceptual to measure to what extent that a firm would fulfill its corporate social responsibility. Chu and Yang [7] therefore contended that corporate social responsibility and stakeholder's benefits were closely related. To measure the degree of fulfilling corporate social responsibility, they further proposed that CSR could be computed from contributions to stakeholders, which were defined as government, employees, creditors, suppliers, and public welfare. Based on the measures of contributions to stakeholders, the study revealed that CSR had a positive impact on firm performance although the impact direction of contributions to different stakeholders might be inconsistent. Generally speaking, literature indicates that there is significant and positive correlation between corporate social responsibility and firm performance.

Although most literature on CSR suggested that a firm, endeavoring to fulfill its social responsibility, might have a better firm performance (see [6,19-21]), yet some studies took a different opinion. For instance, Mahapatra [22] studied how external investors reflected the expenses of pollution prevention firms to stock return, and suggested that external investors behaved as rational economic investors instead of ethical investors. This meant that the expenses of pollution prevention had a negative impact on stock return. In addition, McWalliams and Siegel [23] conducted regression analysis of corporate social responsibility on firm performance, and found that corporate social responsibility had no significant influence on firm performance.

Recent studies on CSR were directed to see the implementation of corporate social responsibility as a dynamic process of strategic investment in a firm. Peters and Mullen [24] found that the effects of corporate social responsibility could be accumulated and reinforced positively in the long-run, thus leading to a better firm performance.

\section{Research Methodology}

Summarized from the proceeding section, corporate social responsibility could be regarded as socially responsible investment (SRI) and strategic investment in a firm from the perspectives of marketing identification and/or strategic management. This study aims to answer the question how stock performance is influenced when firms fulfill their corporate social responsibility. We apply the style portfolio approach by forming three CSR portfolios, examine the stock performance in both the short-run and the long-run relative to bench portfolios, and then test statistical significance of excess returns. As the first step of the methodology, the corporate social responsibility index (CSRI) is constructed on the ground of three dimensions, i.e., economic, social, and environmental, an idea originated from the Dow Jones Sustainability Index (DJSI). Three portfolios according to the CSRI, i.e., high CSR, medium CSR, and low CSR, are established and rebalanced quarterly. Quarterly portfolio returns and cumulative returns are computed to test statistical significance relative to those of benchmark portfolios, i.e., market, value, and growth portfolios.

\subsection{Corporate Social Responsibility Index}

To construct our CSRI, we take the idea in [7] that the 
fulfillment of corporate social responsibility could be measured from socially responsible investment (SRI) contributed to government, employees, creditors, suppliers and public welfare. In addition, as suggested in [6], corporate contribution to stockholders is the fundamental social responsibility of a firm from the perspective of economic responsibility. It is therefore included in the CSRI variable. With regard to a firm's contribution to public welfare, intuitively a firm's monetary donation the purpose of public welfare would serve as an ideal measure for corporate contribution to public welfare. Since the information is not required for a firm to disclose in its financial statements nor it is available in all the published data, we use the data of environmental events as inverse measures for contribution to public welfare. The database of environmental events in TEJ could be reorganized into two useful variables, one of which is the number of the events causing environmental pollution and concerns and the other is the dollar amount that a firm is fined by the government due to the environmental events.

Based on the discussion above, the CSRI variable is therefore constructed on three dimensions, e.g., economic, social, and environmental dimensions, which are described by seven measurable variables. The framework of constructing the CSRI is exhibited in Figure 3.

Since the specific measures and weights in the DJSI World are not announced, our CSRI is constructed on the idea of stakeholders and the basis of data availability. We first define the economic dimension of corporate social responsibility that a firm should make efforts to repay to its funding sources, so the contributions to stockholders and creditors are in this dimension. The social dimension describes that a firm should attempt to fulfill its social responsibility to other stakeholders. Un-

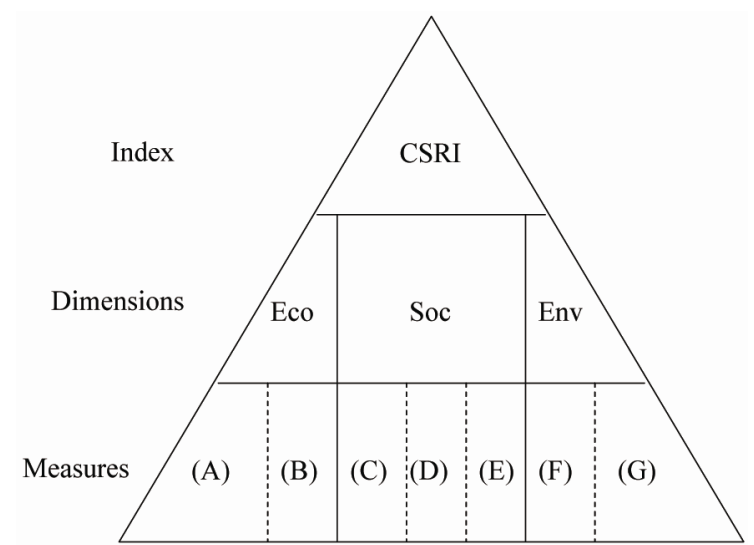

Figure 3. The framework of corporate social responsibility index (CSRI). (A) contributions to creditors; (B) contributions to stockholders; (C) contributions to government; (D) contributions to employees; (E) contributions to suppliers; (F) environmental variable 1; (G) environmental variable 2. der the consideration of data availability, we include the contributions to government, employees, and suppliers in the social dimension. In addition, the environmental dimension is defined as the measures that a firm contributes to protect the environments, including both natural and human environments. Since it extremely difficult to monetarily quantify the efforts of a firm in environmental protection, we use two variables to measure the contributions of a firm in this dimension. The first one depicts how a firm endeavors to avoid environmental hazards and pollutions, i.e., the number of tickets (including warnings) that a firm receives from the government due to causing environmental hazards, while the second one describes the total dollar amount fined by the government due to the environmental incidents.

\subsection{Variable Definitions}

Since the specific measures and weights in the DJSI World are not announced, our CSRI is constructed on the idea of stakeholders and the basis of data availability. We first define the economic dimension of corporate social responsibility that a firm should make efforts to repay to its funding sources, so the contributions to stockholders and creditors are in this dimension. The social dimension describes that a firm should attempt to fulfill its social responsibility to other stakeholders. Under the consideration of data availability, we include the contributions to government, employees, and suppliers in the social dimension. In addition, the environmental dimension is defined as the measures that a firm contributes to protect the environments, including both natural and human environments. Since it extremely difficult to monetarily quantify the efforts of a firm in environmental protection, we use two variables to measure the contributions of a firm in this dimension. The first one depicts how a firm endeavors to avoid environmental hazards and pollutions, i.e., the number of tickets (including warnings) that a firm receives from the government due to causing environmental hazards, while the second one describes the total dollar amount fined by the government due to the environmental incidents.

\subsubsection{Corporate Social Responsibility Index}

As mentioned earlier, our index of corporate social responsibility, CSRI, constitutes economic, social, and environmental dimensions. The economic dimension, denoted by Eco, consists of corporate contributions to funding sources such as stockholders and creditors. The social dimension, denoted by $S o c$, is defined as corporate contributions to the other stakeholders of a company, including the contributions to government, employees, and suppliers. The environmental dimension, denoted by 
Env, is comprised of two specific variables in the TEJ database, the number of tickets issued by the government due to causing environmental hazards and the dollar amount of total fines due to the events of environmental hazards. The computational definitions of the seven measures of corporate social responsibility, three dimensions, and the combined index are given below:

1) Contributions to Stockholder ( $\mathrm{SHCI}$ )

The contributions to stockholders, denoted by SHCI, are referred to as the percentile ranking of earnings per share (EPS). The formula of SHCI is shown below:

$$
\text { SHCI }=\text { Score }(E P S)=\text { Score }\left(\frac{N I-P S D}{O S}\right)
$$

where Score represents the percentile ranking of EPS,

$E P S$ is earning per share,

$N I$ is net profit after tax,

$P S D$ is dividend of preferred stocks,

$O S$ is the weighted average outstanding shares of common stock.

2) Contributions to Creditor (CCI)

The contributions to creditors, denoted by CCI, are measured by the percentile ranking of total interest expense, scaled by total debt. The formula of CCI is given as follows:

$$
C C I=\operatorname{Score}(I E R)=\operatorname{Score}\left(\frac{I E}{D e b t}\right)
$$

where IER is the ratio of total interest expense, IE, to total debt, Debt.

3) Contributions to Government ( $G C I$ )

The contributions to the government, denoted by GCI, are described by the percentile ranking of total tax expense, scaled by sales revenues. The formula of GCI, is given below:

$$
G C I=\operatorname{Score}(T E R)=\operatorname{Score}\left(\frac{T E}{\text { Sales }}\right)
$$

where $T E R$ denotes the ratio of total tax expense, TE, to company sales, Sales.

4) Contributions to Employees (ECI)

The contributions to employees, denoted by ECI, are defined as the percentile ranking of total salary and benefits expenses per employee, scaled by sales. The formula of $E C I$ is given below:

$$
E C I=\operatorname{Score}(A S E R)=\text { Score }\left(\frac{S E / E N}{\text { Sales }}\right)
$$

where ASER stands for salary and benefit expenses, SE, divided by the number of employees, EN, scaled by sales.

5) Contributions to Suppliers (SCI)

The contributions to suppliers, denoted by SCI, are de- fined as the percentile ranking of annual purchase, scaled by sales. The formula of $S C I$ is shown below:

$$
S C I=\operatorname{Score}(P C R)=\operatorname{Score}\left(\frac{P C}{\text { Sales }}\right)
$$

where $P C R$ denotes the ratio of annual purchase, $P C$, to sales.

6) Environmental Variable 1 (EDI)

The first environmental variable, denoted by $E D I$, is scored from the number of events, $E D$, that a firm causes environmental hazards in a year. The data are collected from the Environmental Incident Database in the TEJ and are computed from the inverse percentile ranking of the number of tickets (including warnings) in a year that a firm receives from the government due to causing environmental hazards. This means that the fewer incidents that a firm causes environmental hazards, the higher EDI is. The formula of EDI is shown below:

$$
E D I=\operatorname{Score}^{\prime}(E D)
$$

where Score' stands for the inverse percentile ranking and $E D$ denotes the number of incidents that a firm causes environmental hazards in a year.

7) Environmental Variable 2 (FED)

The second environmental variable, denoted by FED, is the inverse percentile ranking of the dollar amount that a firm is fined by the government due to causing environmental hazards, denoted by $E F$. Similar to EDI, the score of FED is higher as the dollar amount of fines, $E F$, is lower. The formula of FED is given as follows:

$$
F E D=\operatorname{Score}^{\prime}(E F)
$$

8) Score of Economic Dimension (Eco)

The score of economic dimension, denoted by Eco, is the average of SHCI and CCI, as shown below:

$$
E C O=\frac{S H C I+C C I}{2}
$$

9) Score of Social Dimension (Soc)

The score of social dimension, denoted by Soc, is the average of GCI, ECI, and SCI. The formula of Soc is shown below:

$$
S o c=\frac{G C I+E C I+S C I}{3}
$$

10) Score of Environmental Dimension (Env)

The score of environmental dimension, denoted by $E n v$, is the average of EDI and FED. The formula of Env is given below:

$$
E n v=\frac{E D I+F E D}{2}
$$

11) Corporate Social Responsibility Index (CSRI) 
The index of corporate social responsibility, denoted by CSRI, is computed from the average of the scores of three dimensions, i.e., Eco, Soc, and Env. The formula of CSRI is given as follows:

$$
C S R I=\frac{E c o+S o c+E n v}{3}
$$

Three CSR portfolios are constructed according to the CSRI scores. That is, the high CSR (denoted by HCSR) portfolio is chosen from the top 30 stocks of the CSRI in each quarter, the medium CSR (denoted by MCSR) portfolio is the middle 30 stocks of the CSRI, and the low CSR (denoted by LCSR) portfolio is the lowest 30 stocks of the CSRI. Three portfolios are rebalanced quarterly to keep portfolio characteristics consistent. In addition, three benchmark portfolios are also chosen to test statistical significance of three CSR portfolios. To maintain the characteristic of CSR, the CSR portfolios are constructed by the decreasing weights. Specifically, the weight of the $i$-th stock is computed as follows:

$$
W_{i}=\frac{n-i+1}{\sum_{j=1}^{n} j}
$$

\subsubsection{Benchmark Portfolios}

To test statistical significance of stock returns in the style portfolios, we choose market, value, and growth portfolios as the benchmark portfolios. The definitions of the benchmark portfolios are given below:

1) Market

We use the market index to proxy stock return of the market portfolio, denoted by $M$. Market return, $R m$, is calculated as follows:

$$
R m_{t}=\frac{X_{t+1}-X_{t}}{X_{t}}
$$

where $X$ denotes the TWSE Total Market Index.

2) Value Portfolio

The value portfolio, denoted by $V$, is constructed and based on three commonly used value ratios, i.e., price-toearning ratio $(P E R)$, price-to-book ratio $(P B R)$, and priceto-sales ratio (PSR). The value score (Value) is computed from the inverse percentile ranking scores of three value ratios and the value portfolio is chosen from the top 30 stocks of the value score. The definition of Value is given below:

$$
\text { Value }=\frac{\text { Score }^{\prime}(P E R)+\operatorname{Score}^{\prime}(P B R)+\operatorname{Score}^{\prime}(P S R)}{3}
$$

3) Growth Portfolio

The growth portfolio, denoted by $G$, is constructed and based on three commonly used growth ratios, i.e., asset growth $(A G)$, equity growth $(E G)$, and sales growth (SG). The growth score (Growth) is computed from the percentile ranking scores of three growth ratios and the growth portfolio is chosen from the top 30 stocks of the growth score. The definition of Growth is given below:

$$
\text { Growth }=\frac{\operatorname{Score}(A G)+\operatorname{Score}(E G)+\operatorname{Score}(S G)}{3}
$$

It is important to point out that the portfolio weights in both of the value and growth portfolios are formed in the same way as those of the CSR portfolios in order to keep the portfolio characteristics.

\subsubsection{Stock Returns}

In the study, two measures of stock returns are adopted, i.e., quarterly return, $Q R$, and cumulative return, $C R$. The former is used to represent stock performance in the short-run, and the latter does that in the long-run. $Q R$ is defined as follows:

$$
Q R_{t}=\sum_{i=1}^{n} W_{i, t} R_{i, t}
$$

where $R_{i, t}$ denotes the return of stock $i$ at time $t$.

In addition, $C R$ is calculated as follows:

$$
C R_{t}=\left[\prod_{j=1}^{t}\left(1+Q R_{j}\right)\right]^{\frac{1}{t}}-1
$$

\subsection{Research Hypotheses}

To test whether quarterly returns of three CSR portfolios are significantly higher than those of bench portfolios, the null hypothesis $\left(H_{0}\right)$ and the alternative hypothesis $\left(H_{1}\right)$ are established as follows, respectively:

$$
\begin{aligned}
& H_{0}: Q R_{S} \leq Q R_{B} \\
& H_{1}: Q R_{S}>Q R_{B}
\end{aligned}
$$

In addition, to test statistical significance of cumulative returns, we set up the null hypothesis $\left(H_{0}\right)$ and the alternative hypothesis $\left(H_{1}\right)$ as follows, respectively:

$$
\begin{gathered}
H_{0}: C R_{S} \leq C R_{B} \\
H_{1}: C R_{S}>C R_{B}
\end{gathered}
$$

To test statistical significance of quarterly returns and cumulative returns, a method of one-sided, pair-wise $t$ statistic testing is applied for this purpose. For the ease of understanding, all the hypotheses of interest, each of which includes two sub-hypotheses to test statistical significance, are summarized in Table 1. 
Table 1. Research hypotheses.

\begin{tabular}{|c|c|c|c|}
\hline Hypothesis & -Hypothesis & Null Hypothesis & Alternative Hypothesis \\
\hline \multirow[t]{2}{*}{ H1 } & H1-1 & $Q R_{H C S R} \leq Q R_{M}$ & $Q R_{H C S R}>Q R_{M}$ \\
\hline & H1-2 & $C R_{H C S R} \leq C R_{M}$ & $C R_{H C S R}>C R_{M}$ \\
\hline \multirow[t]{2}{*}{$\mathrm{H} 2$} & $\mathrm{H} 2-1$ & $Q R_{H C S R} \leq Q R_{V}$ & $Q R_{H C S R}>Q R_{V}$ \\
\hline & $\mathrm{H} 2-2$ & $C R_{H C S R} \leq C R_{V}$ & $C R_{H C S R}>C R_{V}$ \\
\hline \multirow[t]{2}{*}{ H3 } & H3-1 & $Q R_{H C S R} \leq Q R_{G}$ & $Q R_{H C S R}>Q R_{G}$ \\
\hline & H3-2 & $C R_{H C S R} \leq C R_{G}$ & $C R_{H C S R}>C R_{G}$ \\
\hline \multirow[t]{2}{*}{$\mathrm{H} 4$} & $\mathrm{H} 4-1$ & $Q R_{M C S R} \leq Q R_{M}$ & $Q R_{M C S R}>Q R_{M}$ \\
\hline & $\mathrm{H} 4-2$ & $C R_{M C S R} \leq C R_{M}$ & $C R_{M C S R}>C R_{M}$ \\
\hline \multirow[t]{2}{*}{ H5 } & $\mathrm{H} 5-1$ & $Q R_{M C S R} \leq Q R_{V}$ & $Q R_{M C S R}>Q R_{V}$ \\
\hline & $\mathrm{H} 5-2$ & $C R_{M C S R} \leq C R_{V}$ & $C R_{M C S R}>C R_{V}$ \\
\hline \multirow[t]{2}{*}{ H6 } & H6-1 & $Q R_{M C S R} \leq Q R_{G}$ & $Q R_{M C S R}>Q R_{G}$ \\
\hline & H6-2 & $C R_{M C S R} \leq C R_{G}$ & $C R_{M C S R}>C R_{G}$ \\
\hline \multirow[t]{2}{*}{ H7 } & H7-1 & $Q R_{L C S R} \leq Q R_{M}$ & $Q R_{L C S R}>Q R_{M}$ \\
\hline & $\mathrm{H} 7-2$ & $C R_{L C S R} \leq C R_{M}$ & $C R_{L C S R}>C R_{M}$ \\
\hline \multirow[t]{2}{*}{$\mathrm{H} 8$} & H8-1 & $Q R_{L C S R} \leq Q R_{V}$ & $Q R_{L C S R}>Q R_{V}$ \\
\hline & $\mathrm{H} 8-2$ & $C R_{L C S R} \leq C R_{V}$ & $C R_{L C S R}>C R_{V}$ \\
\hline \multirow[t]{2}{*}{ H9 } & H9-1 & $Q R_{L C S R} \leq Q R_{G}$ & $Q R_{L C S R}>Q R_{G}$ \\
\hline & H9-2 & $C R_{L C S R} \leq C R_{G}$ & $C R_{L C S R}>C R_{G}$ \\
\hline
\end{tabular}

The data of the study is sampled from publicly listed companies of Taiwan Stock Exchange and obtained from Taiwan Economic Journal for the period of 2001-2009. Since style portfolios are rebalanced quarterly, there are 36 quarters in the period of the study. In addition, firms in the financial industry are subject to different accounting standards and market regulations, so they are excluded from the sample to avoid systematic bias.

\section{Research Results}

\subsection{Descriptive Statistics}

Descriptive statistics are conducted on the sample to screen data characteristics and distributions. Descriptive statistics of all variables are displayed in Table 2.

As shown in Table 2, the mean, median, and standard deviation of EPS in the economic dimension are 1.901, 1.340, and 3.613, respectively. Since EPS ranges from
Table 2. Descriptive statistics.

\begin{tabular}{|c|c|c|c|c|c|c|}
\hline Dimensions & Variables & Mean & Median & S.D. & Max & Min \\
\hline \multirow{3}{*}{ Economic } & EPS & 1.901 & 1.340 & 3.613 & 47.850 & -13.24 \\
\hline & $J E R$ & 0113 & & 0112 & 0327 & 0.000 \\
\hline & TER & 0.015 & 0.008 & 0.048 & 1.093 & -0.926 \\
\hline \multirow[t]{3}{*}{ Social } & ASER & 0.041 & 0.040 & 0.035 & 0.774 & 0.010 \\
\hline & $P C R$ & 0.223 & 0.148 & 0.411 & 9.302 & 0.050 \\
\hline & $E D$ & 0.179 & 0.000 & 0.616 & 15.000 & 0.000 \\
\hline \multirow[t]{2}{*}{ Environmental } & $\begin{array}{c}E F \\
(\text { in } N T \$ 1,000)\end{array}$ & 111.08 & 18.000 & 214.85 & 3,050 & 0.000 \\
\hline & Eco & 0.498 & 0.501 & 0.163 & 0.956 & 0.002 \\
\hline \multirow[t]{2}{*}{$\begin{array}{c}\text { CSR } \\
\text { Dimensions }\end{array}$} & Soc & 0.489 & 0.489 & 0.177 & 0.996 & 0.014 \\
\hline & Env & 0.500 & 0.500 & 0.205 & 1.000 & 0.001 \\
\hline \multirow[t]{2}{*}{ CSR Index } & CSRI & 0.496 & 0.497 & 0.182 & 0.984 & 0.005 \\
\hline & $Q R_{H C S R}$ & 0.046 & 0.052 & 0.087 & 0.216 & -0.210 \\
\hline \multirow[t]{3}{*}{$\begin{array}{c}\text { CSR } \\
\text { Portfolios }\end{array}$} & $Q R_{M C S R}$ & 0.030 & 0.029 & 0.127 & 0.407 & -0.246 \\
\hline & $Q R_{L C S R}$ & 0.020 & 0.031 & 0.105 & 0.264 & -0.210 \\
\hline & $Q R_{M}$ & 0.034 & 0.048 & 0.153 & 0.545 & -0.244 \\
\hline \multirow[t]{2}{*}{$\begin{array}{l}\text { Benchmark } \\
\text { Portfolios }\end{array}$} & $Q R_{V}$ & 0.085 & 0.076 & 0.127 & 0.359 & -0.176 \\
\hline & $Q R_{G}$ & 0.041 & 0.060 & 0.128 & 0.386 & -0.264 \\
\hline
\end{tabular}

-13.240 to 47.850 , it appears that profitability in the sample firms is quite diverse. In addition, the mean, median, and standard deviation of IER are $0.113,0.111$, and 0.112 , respectively, indicating that the overall debt does not seriously burden firms in the sample. Besides, the minimum value of IER is 0 , meaning that there are some companies operating unleveredly.

The social dimension consists of three variables, TER, $A S E R$, and PCR. The mean and median of corporate tax rate, TER, are 0.015 and 0.008 , indicating that the actual corporate tax rate, on average, in Taiwan is not very high compared to other developed countries. In addition, the mean, median, and standard deviation of ACER are 0.041, 0.040 , and 0.035 , respectively. The low average salary 
rate indicates that most firms in Taiwan are not quite labor-intensive. In contrast, the mean, median, and standard deviation of PCR are $0.223,0.148$, and 0.411 , respectively, suggesting that purchase would accounts for a large part in the cost structures of most firms.

The environmental dimension consists of two variables, $E D$ and $E F$. The mean, median, standard deviation, max, and min of $E D$ are $0.179,0.000,0.616,15.000$, and 0.000 , and those of $E F$ are 111.08, 18.000, 214.850, 3050 , and 0 . These statistics indicate that there is a large difference for firms causing environmental concerns. Some firms never commit any incidents of environmental protection, while another would violate up to 15 times of environmental regulations in a year. The fines of these incidents therefore range from $3,050,000$ to $0 \mathrm{NT}$ dollars.

The mean, median, standard deviation, max, and min of CSRI are 0.496, 0.497, 0.182, 0.984, and 0. Since the method of percentile ranking is applied to score the corporate social responsibility index, it follows that CSRI is quite close to uniformedly distributed.

Both quarterly returns and cumulative returns over the study period are demonstrated in Figure $\mathbf{4}$ and Figure 5, respectively, to exhibit stock performance of all style portfolios. As shown in Figure 4, in the period the market appears to have three major troughs $(2001,2002$, and 2008) and three major peaks $(2001,2002,2003$, and 2009). Also, it is worth noting that in Figure 5 the value, high CSR, and growth portfolios outperform the market, yet this needs conducting hypothesis testing.

\subsection{Hypothesis Testing}

As mentioned earlier, to test statistical significance whether the CSR portfolios outperform the benchmark portfolios, a method of one-sided, pair-wise $t$ statistic

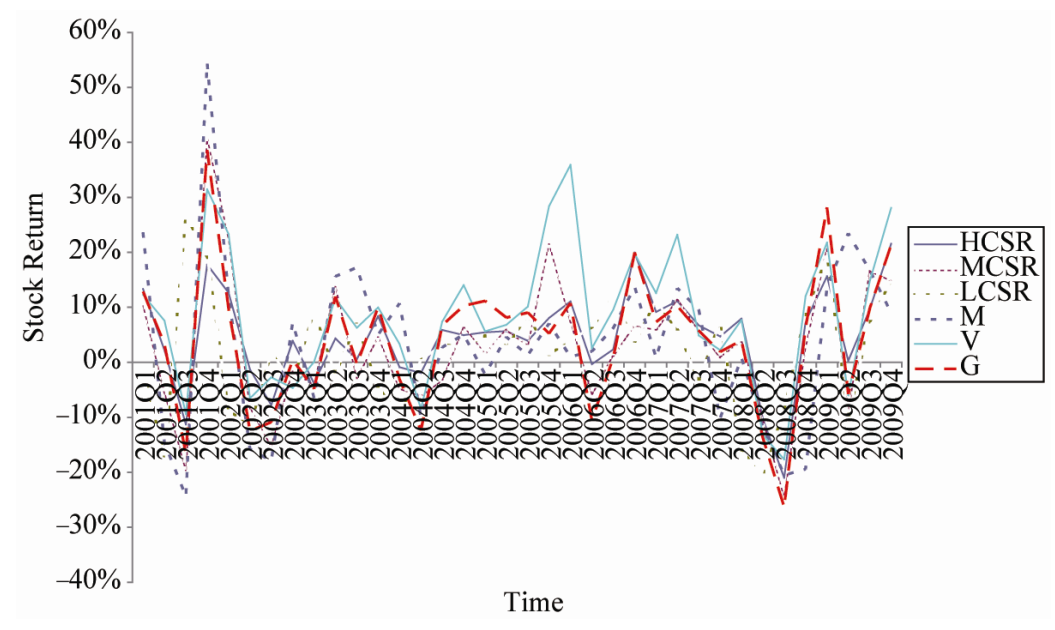

Figure 4. Quarterly returns of all style portfolios.

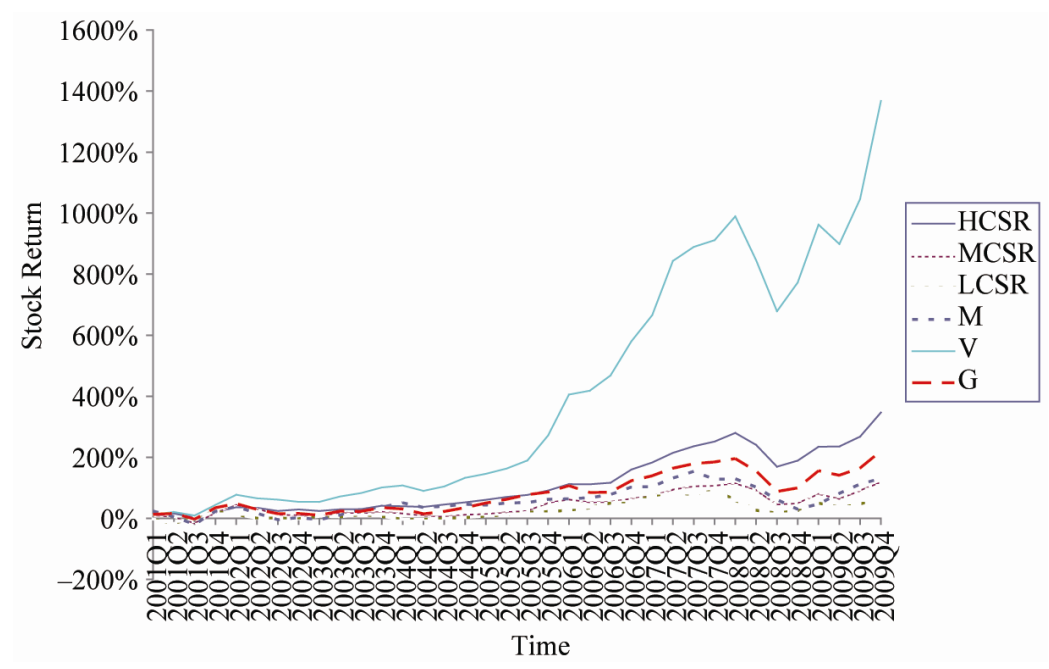

Figure 5. Cumulative returns of all style portfolios. 
testing is applied. The results are exhibited in Table 3.

As shown in Table 3, all the hypotheses testing the significance of excess returns of the CSR portfolios are rejected, meaning that there are no significant excess returns of the three CSR style portfolios relative to the benchmark portfolios. However, Table 3 indicates that the $t$ statistics of the high CSR portfolio relative to market (H1-2) and the growth portfolio (H3-2) are $5.4300(p$ $<0.01)$ and $5.3445(p<0.01)$, respectively, thus rejecting the null hypothesis and accepting the alternative hypothesis. This means that the high CSR portfolios outperform the market and the growth portfolio in the longrun in term of cumulative returns. By contrast, stock performance of both the MCSR and LCSR portfolios is insignificant in both the short-run and the long-run. These results reveal that more socially responsible firms could perform better than less socially responsible firms in stock market.

Since the cumulative returns for the HCSR, M, and G portfolios over the study period are 4.4713, 2.3101, and 3.2092 , respectively, the annualized return for the three portfolios are $0.1811,0.0975$, and 0.1383 , respectively ${ }^{1}$. This result indicates that the high CSR portfolio on average has a higher excess return of $8.36 \%$ and $4.28 \%$ relative to the market and the growth portfolio, respectively. It is possible that socially responsible firms may have better corporate image perceived by investors, thus

Table 3. The results of hypothesis testing.

\begin{tabular}{|c|c|c|c|}
\hline Hypothesis & Sub-Hypothesis & $t$ Statistic & $p$ Value \\
\hline \multirow{2}{*}{ H1 } & $\mathrm{H} 1-1$ & 0.6034 & 0.2751 \\
\hline & $\mathrm{H} 1-2$ & 5.4300 & $0.0000^{* *}$ \\
\hline \multirow{2}{*}{$\mathrm{H} 2$} & $\mathrm{H} 2-1$ & -3.3537 & 0.9990 \\
\hline & $\mathrm{H} 2-2$ & -5.8678 & 0.9999 \\
\hline \multirow{2}{*}{ H3 } & H3-1 & 0.5499 & 0.2930 \\
\hline & H3-2 & 5.3445 & $0.0000^{* *}$ \\
\hline \multirow{2}{*}{$\mathrm{H} 4$} & $\mathrm{H} 4-1$ & -0.2858 & 0.3883 \\
\hline & $\mathrm{H} 4-2$ & -4.0736 & 0.0001 \\
\hline \multirow{2}{*}{ H5 } & H5-1 & -4.8971 & 0.9999 \\
\hline & $\mathrm{H} 5-2$ & -6.0162 & 0.9999 \\
\hline \multirow{2}{*}{ H6 } & H6-1 & -1.1296 & 0.1332 \\
\hline & H6-2 & -7.5288 & 0.9999 \\
\hline \multirow{2}{*}{$\mathrm{H} 7$} & H7-1 & -0.5163 & 0.3044 \\
\hline & H7-2 & -7.7140 & 0.9999 \\
\hline \multirow{2}{*}{ H8 } & H8-1 & -2.9650 & 0.9972 \\
\hline & $\mathrm{H} 8-2$ & -6.1386 & 0.9999 \\
\hline \multirow{2}{*}{$\mathrm{H} 9$} & H9-1 & -0.9624 & 0.1712 \\
\hline & H9-2 & -8.1043 & 0.9999 \\
\hline
\end{tabular}

${ }^{1}$ The annual return is calculated from the following equation:

$$
A R_{t}=\left(1+C R_{t}\right)^{\frac{1}{t}}-1
$$

where $A R$ denotes the annualized return. leading to better stock performance. Therefore, our result finds evidence supporting the CSR effect in Taiwan. Since the impact is significantly positive, it is concluded that a social investment to a firm is as important as a capital investment. Just as suggested by Porter and Kramer [2], a firm should regard a socially responsible investment as one of its core business strategies.

In addition, our results also indicate that the value portfolio has the highest stock returns over the other style portfolios in both the short-run and the long-run. The annualized return is calculated to be $34.78 \%$, significantly higher than that of the CSR, the market, and the growth portfolios. Thus, this result finds evidence supporting the value effect in Taiwan.

\section{Conclusions}

In the world economy on the trend of increasing globalization, value maximization is no longer the only corporate goal for a firm. A successful, responsible firm should eye on corporate growth while in the meantime rigorously endeavoring to enhance social growth. In this new definition of dual corporate goals, a firm should take their social responsibility to all the corporate stakeholders, including stockholders, creditors, employees, suppliers, government and environment. In particular, a socially responsible firm should not only focus on traditional issues of business ethics, but also on how they could contribute to corporate stakeholders in order to advance social growth. Therefore, the fulfillment of corporate social responsibility should be re-defined in a more comprehensive manner to include proactive contributions to economy, society, and environment.

This study is based upon the framework of Dow Jones Sustainability Index (DJSI) and the arguments suggested in $[6,7]$. The former is built upon the idea of measuring the degree to which a firm fulfills its corporate social responsibility from the aspects of its contributions to economy, society, and environment, while the latter proposes that the measurement of a firm's fulfilling its corporate social responsibility should consider corporate contributions to stakeholders, such as government, employees, creditors, and suppliers. In this study, the contributions to stockholders and public welfare are also integrated into our framework to measure a firm's fulfillment of corporate social responsibility. Therefore, our framework of measuring corporate social contributions is built upon economic, social, and environmental dimensions. The economic dimension measures corporate contributions to financial provisions such as stockholders and creditors. The social dimension gauges corporate contributions to the other corporate stakeholders, such as government, employees, and suppliers. Finally, the en- 
vironmental dimension quantifies a firm's efforts to reduce environmental hazards. Due to the difficulty of data collection, the environmental dimension is measured inversely from the number of environmental hazards and the fines due to the violations.

Based on our framework for evaluating the fulfillment of corporate social responsibility, the study aims to investigate the impact of fulfilling corporate social responsibility on corporate stock performance. Specifically, we argue that when a firm makes efforts to fulfill its social responsibility, it would not only increase its socially responsible investment, but also improve its corporate image so as to attract interested investors in the stocks, thus causing a favorable stock performance. Sampled from Taiwan publicly listed firms in the period of 2001-2009, the study is thus far the first one empirically examining the impact of corporate social responsibility on stock performance by the style portfolio approach.

Our results find supporting evidence that when a firm endeavors to fulfill its corporate social responsibility, it has a positive impact on stock performance, relative to the market and the growth portfolios. The implication is that the implementation of corporate social responsibility does not necessarily result in additional operating costs and/or expenses. On the contrary, a socially responsible firm may be welcome by investors due to better corporate image, thus having a positive impact on stock returns. The findings are consistent with the conclusions in [5-7, 19,21,24].

Generally speaking, our findings indicate that fulfilling corporate social responsibility does not necessarily contradict with the goal of maximizing firm value. Since the implementation of corporate social responsibility is positively associated with firm performance, management should treat socially responsible investment as a core business strategy, which would pave a way for a firm's perpetual growth. More specifically, a firm could serve as a good corporate citizen, while in the meantime pursuing the growth of stockholder's wealth.

\section{References}

[1] K. Ohmae, "Crisis and Business Opportunity of Bourgeoisie Disappearance in M-Shape Society," Business Weekly, 2007, Taiwan.

[2] M. E. Porter and M. R. Kramer, "Strategy and Society: The Link between Competitive Advantage and Corporate Social Responsibility," Harvard Business Review, Vol. 84, No. 12, 2006, pp. 78-92.

[3] G. Laczniak and P. Murphy, "Fostering Ethical Marketing Decisions," Journal of Business Ethics, Vol. 10, No. 4, 1991, pp. 259-271. doi:10.1007/BF00382965

[4] R. L. Sims and K. G. Kroeck, "The Influence of Ethics
Fit on Employee Satisfaction, Commitment and Turnover," Journal of Business Ethics, Vol. 10, No. 4, 1994, pp. 259-271.

[5] L. E. Preston and D. P. O'Bannon, "The Corporate Social-Financial Performance Relationship: A Typology and Analysis," Business and Society, No. 36, No. 4, 1997, pp. 419-429. doi:10.1177/000765039703600406

[6] I. Maignan, O. C. Ferrell, and L. Ferrell, "A Stakeholder Model for Implementing Social Responsibility in Marketing," European Journal of Marketing, Vol. 39, No. 9/ 10, 2005, pp. 956-977. doi:10.1108/03090560510610662

[7] C. F. Chu and P. P. Yang, "Empirical Examination of Relationship between Corporate Social Responsibility and Financial Performance," Financial Forum, Vol. 7, 2009, pp. 135-137.

[8] S. Vyakarnam, A. Bailey, A. Myers and D. Burnett, "Towards an Understanding of Ethical Behavior in Small Firms," Journal of Business Ethics, Vol. 16, No. 15, 1997, pp. 1625-1636. doi:10.1023/A:1022452502299

[9] L. J. Brooks, "Corporate Ethical Performance: Trends, Forecasts and Outlooks," Journal of Business Ethics, Vol. 8, 1989, pp. 39-50.

[10] S. Rosenthal and R. A. Buchholz, "Bridging Environmental and Business Ethics: A Pragmatic Framework," Environmental Ethics, Vol. 20, No. 4, 1998, pp. 394-408.

[11] R. N. Lussier, "Management Fundamentals," Thomson Learning, Inc., New York, 2000.

[12] O. C. Ferrell and H. Geoffrey, "Business: A Changing World," McGraw-Hill, New York, 2000.

[13] K. Davis and R. L. Blomstrom, "Environment and Responsibility," Business and Society, 3rd Edition, McGraw Hill, New York, 1975.

[14] A. B. Carroll, "A Three-Dimensional Conceptual Model of Corporate Social Performance," Academy of Management Review, Vol. 4, 1979, pp. 497-505.

[15] D. J. Wood, "Corporate Social Performance Revisited," Academy of Management Review, Vol. 16, 1991, pp. 691718.

[16] R. L. Daft, "Organization Theory and Design," SouthWestern College Publishing, Cincinnati, 2003.

[17] D. Vogel, "Is There a Market for Virtue? A Critical Appraisal of Corporate Social Responsibility," The Third Transatlantic Business Ethic Conference, Barcelona, 1-3 October 2004

[18] A. B. Carroll, "The Pyramid of Corporate Social Responsibility: Toward the Moral Management of Organizational Stakeholders," Business Horizons, Vol. 34, No. 4, 1991, pp. 39-48. doi:10.1016/0007-6813(91)90005-G

[19] C. C. Verschoor, "A Study of the Link between a Corporation's Financial Performance and Its Commitment of Ethics," Journal of Business Ethics, Vol. 17, No. 13, 1998, pp. 1509-1516. doi:10.1023/A:1006020402881

[20] I. Maignan and O. C. Ferrell, "Corporate Social Responsibility and Marketing: An Integrative Framework," Journal of Academy of Marketing Science, Vol. 32, No. 1, 2004, pp. 3-19. doi:10.1177/0092070303258971 
[21] J. J. Griffin and J. F. Mahon, "The Corporate Social Performance and Corporate Financial Performance Debate: Twenty-Five Years of Incomparable Research," Business and Society, Vol. 36, No. 1, 1997, pp. 5-31. doi: $10.1177 / 000765039703600102$

[22] S. Mahapatra, "Investor Reaction to a Corporate Social Accounting," Journal of Business Finance \& Accounting, Vol. 11, No. 1, 1984, pp. 29-40. doi:10.1111/j.1468-5957.1984.tb00054.x
[23] A. McWilliams and D. Siegel, "Corporate Social Responsibility and Financial Performance: Correlation or Misspecification?" Strategic Management Journal, Vol. 21, No. 5, 2000, pp. 603-609.

[24] R. Peters and M. R. Mullen, "Some Evidence of the Cumulative Effects of Corporate Social Responsibility on Financial Performance," Journal of Global Business Issues, Vol. 3, No. 1, 2009, pp. 1-14. 